\title{
Article
}

\section{Career Choice Self-Efficacy Source Scale: Development and Initial Psychometric Studies}

\author{
Thaline da Cunha Moreira ${ }^{1, *}$ \\ Orcid.org/0000-0002-6484-8583 \\ Rodolfo Augusto Matteo Ambiel ${ }^{1}$ \\ Orcid.org/0000-0002-3921-8547 \\ Maiana Farias Oliveira Nunes ${ }^{2}$ \\ Orcid.org/0000-0003-4891-5982 \\ ${ }^{1}$ Universidade São Francisco, Campinas, SP, Brasil \\ ${ }^{2}$ Universidade Federal de Santa Catarina, Florianópolis, SC, Brasil
}

\begin{abstract}
Assessment in career counseling can involve various constructs, including that of career choice selfefficacy, which refers to one's belief in one's ability to engage in career decision-making activities. However, the literature is still incipient in relation to the assessment of the sources of self-efficacy for making career choices. Accordingly, the present study's aim was to develop the Career Choice SelfEfficacy Source Scale (Escala de Fontes de Autoeficácia para Escolha Profissional, or EFAEP; initials in Portuguese). The development process involved the formulation of the items as well as pilot data collection. Upon concluding the scale's developmental phase, we began data collection, which enjoyed the participation of 388 students between the ages of 14 and 19 years from public and private high schools in the state of São Paulo. In addition to the EFAEP, the students also responded to the Career Choice Self-Efficacy Scale (Escala de Autoeficácia para Escolha Profissional, or EAE-EP; initials in Portuguese). Principal component analysis was performed, and a three-factor structure exhibited the best fit, with Cronbach's alphas ranging between 0.81 and 0.73 . Furthermore, all of the EFAEP's factors displayed positive correlations with the EAE-EP's factors. The study's results and limitations are discussed in relation to the literature on the subject.
\end{abstract}

Keywords: Self-efficacy, career counseling, psychological assessment.

\section{Escala de Fontes de Autoeficácia para Escolha Profissional: Construção e Estudos Psicométricos Iniciais}

\section{Resumo}

A avaliação em orientação profissional pode envolver diversos construtos, entre eles o da autoeficácia para escolha profissional, que se refere às crenças quanto à capacidade de se engajar em atividades de decisão profissional. Contudo, a literatura ainda é incipiente quanto a avaliação das fontes de

Mailing address: Universidade São Francisco, Campus de Campinas, Rua Waldemar César da Silveira, 105, Jardim Cura D’Ars, Campinas, SP, Brazil 13045-510. E-mail: thacmoreira@gmail.com, rodolfo.ambiel@usf. edu.br and maiananunes@mac.com

Support: Coordenação de Aperfeiçoamento de Pessoal de Nível Superior (CAPES). 
autoeficácia em tal domínio. Assim, o presente estudo teve por objetivo a construção da Escala de Fontes de Autoeficácia para Escolha Profissional (EFAEP). O processo de construção envolveu a formulação dos itens e a coleta piloto. Finalizado o processo de construção, deu-se início a coleta de dados, da qual participaram 388 estudantes das três séries do ensino médio, com idades entre 14 e 19 anos, de escolas públicas e particulares do interior do estado de São Paulo. Além da EFAEP, os alunos também responderam à Escala de Autoeficácia para Escolha Profissional (EAE-EP). Análises de componentes principais foram realizadas e uma estrutura com três fatores apresentou o melhor ajuste, com alfas de Cronbach variando entre 0,81 e 0,73. Além disso, todos os fatores da EFAEP se correlacionaram positivamente com os fatores da EAE-EP. Os resultados e limitações do estudo são discutidos de acordo com a literatura sobre $o$ assunto.

Palavras-chave: Autoeficácia, orientação profissional, avaliação psicológica.

\section{Escala de Fontes de Autoeficácia para Escolha Profissional: Construcción y Estudios Psicométricos Iniciales}

\section{Resumen}

La evaluación de la orientación vocacional puede envuelve diversos constructos, entre los cuales está la autoeficacia para decisión profesional, que se refiere a las convicciones de la capacidad de envolverse en la actividad de decisión profesional. Sin embargo, la literatura es incipiente como la evaluación de las fuentes de autoeficácia en la decisión profesional. De esta forma, el presente estudio tuvo el objetivo de construir la Escala de Fontes de Autoeficácia para Escolha Profissional (EFAEP). Lo proceso de elaboración implica la formulación de los ítems e la colecta piloto. Finalizando el proceso de elaboración, se Dio continuidad a la colecta de datos, de la cual participaron 388 estudiantes de los tres años de secundaria superior, con edades entre 14 y 19 años, de escuelas públicas y privadas del interior de São Paulo, Brasil. Además de la EFAEP, los estudiantes también respondiero la Escala de Autoeficácia para Escolha Profissional (EAE-EP). Fueron realizadas análisis de los principales componentes e de la una estructura de tres factores que presentó mejor ajuste, con alfas de Cronbach entre 0.81 y 0.73 . Además, todos los factores de EFAEP correlacionan positivamente con los factores de EAE-EP. Los resultados y limitaciones del estudio son discutidos de acuerdo con la literatura del asunto.

Palabras clave: Autoeficacia, orientación vocacional, evaluación psicológica.

Self-efficacy beliefs relate to confidence in one's capacity to organize and carry out specific actions in order to attain certain achievements (Bandura, 1997). This construct is an integral part of Bandura's (1977) Social Cognitive Theory, which introduces both the view point according to which individuals are the agents of their own actions and the notion that people undergo a dynamic process (known as reciprocal determinism) that involves interactions between behavior, environmental factors and personal factors (Azzi, Vieira, Iaochite, Ferreira, \& Guerreiro-Casanova, 2014; Bandura, 2008; Pajares \& Olaz, 2008).
Playing a vital role among such concepts, self-efficacy beliefs also influence human motivation, individual achievements and emotional states, as well as being an integral part of the self-regulation of human behavior and cognition, affecting the amount of effort dedicated to a task and the perseverance and resilience required to face difficulties (Bandura, 2009; $\mathrm{Pa}-$ jares, 2002; Pajares \& Olaz, 2008). Such beliefs take the form of a series of dynamic self-beliefs, acting in a particular situation (Lent, Brown, \& Hackett, 1994). They can be applied in a specific field of work - such as afield related to science (Britner \& Pajares, 2006) or mathematics (Usher 
\& Pajares, 2009), or in the career development context (Betz \& Luzzo, 1996) - and they can be assessed in a general manner, although their utility is more restricted in this case (Bandura, 1997).

Self-efficacy beliefs are developed based on four information sources: enactive mastery experiences, vicarious experiences, verbal persuasion and physiological/emotional states (Bandura, 1997). In the present study, we opted for employing the source nomenclature recommended by Nunes and Noronha (2011).

The first source (known as enactive mastery experiences or personal experiences) exerts the greatest influence on self-efficacy beliefs because it involves interpreting prior experiences. This source furnishes legitimate information in relation to a person's behavior, indicating his/ her chances of succeeding in a particular activity (Bandura, 1997; Pajares, 2002). Successful situations tend to strengthen self-efficacy beliefs, while failure tends to weaken them, particularly when it occurs early on or when it provides no relevant information as to the effort itself. New experiences are apportioned in "doses" in line with the individual's preexisting perceptions, being incorporated into his/her prior beliefs (Nunes, 2008).

The second source (known as vicarious experiences or vicarious learning) refers both to observing other people executing a certain task and to making inferences as to one's own capacity based on comparisons with other people who are considered similar (Pajares, 2002). This information source tends to be less efficient than the first source, but it can be pertinent when people doubt their own capacity or lack prior experience in a certain area. Seeing other people succeeding or failing in an activity can improve or worse none's assessment of self-efficacy (Bandura, 1997; Pajares, 2002).

The third information source (known as verbal persuasion) refers to other people's verbal opinions that are transmitted in the form of positive or negative feedback that can either strengthen or weaken one's self-efficacy beliefs (Pajares, 2002). The usefulness of this source is limited when there is no real likely hood of the individual successfully performing the task. Nonetheless, when the individual receives positive feedback, he/she can make greater efforts to carry out the required action. Verbal persuasion's impact on self-efficacy belief development is even greater when individuals believe there is some likelihood that their behavior will produce the expected outcome (Bandura, 1997).

The fourth and final self-efficacy information source relates to how people interpret their physiological and emotional states, such as anxiety, stress and mood. Individuals can acquire some information about their self-efficacy by evaluating their emotional and physiological state while performing a task. Their somatic and emotional reactions act as an indicator of success or failure in the activity. Anxiety, fear and negative thoughts concerning one's capabilities can lower one's perceived self-efficacy, causing stress and, consequently, poor performance. In order to enhance one's perceived self-efficacy, it is important to promote emotional well-being and reduce negative emotional states (Pajares, 2002; Pajares \& Olaz, 2008).

Self-efficacy sources furnish information that is relevant to the development of self-efficacy beliefs, becoming integrated with them by way of cognitive and reflexive processing. Furthermore, personal, social and circumstantial factors can influence the way in which an individual interprets such information (Bandura, 1997). Hence, the four information sources are not responsible for producing a "direct" assessment of one's perception of self-efficacy due to the fact that judgments of one's competence, perceptions of one's weakness or strength, result from the way people interpret the situations they experience, which contributes to strengthening or weakening their self-efficacy beliefs (Nunes, 2008; Pajares \& Olaz, 2008).

The self-efficacy sources can function independently or concurrently; hence, at the same time that people assess their prior experiences and the efforts they dedicate to a task, they also observe the behavior of individuals that are similar to them, receive some form of feedback as to their performance and evaluate their physical and emotional state. Since the sources interact 
mutually, each source, depending on its strength, can influence the development of beliefs to a greater or lesser extent (Nunes, 2008).

The information furnished by the sources for the development of self-efficacy beliefs can come from the most varied environments in which the individual may find himself, varying according to the culture that he/she is a part of and the field in which it is being applied (Ahn, Usher, Butz, \& Bong, 2016). As aforementioned, the self-efficacy construct must be applied within specific contexts of performance; for example, it can be studied within the career-counseling context (Nunes \& Noronha, 2011).

Within the context of studies focusing on careers, the Social Cognitive Career Theory (SCCT), which was proposed by Lent et al. (1994), has stood out. By way of this theory, the authors presented a theoretical framework for understanding career development, which is contextualized into the following three phases: development of vocational interests; academic and career choices; and performance in such activities. The principal theoretical reference for the development of this theory was Bandura's Social Cognitive Theory (SCT, 1977), of which two constructs were employed as a main point: self-efficacy and outcome expectations (Lent et al., 1994).

The SCCT is considered an improvement to the model proposed by Hackett and Betz (1981), who were pioneers in terms of applying self-efficacy to women within the career development context. Subsequently, Taylor and Betz (1983) proposed the Career Decision-Making Self-Efficacy Scale (CDMSE), an instrument used for assessing this construct.

Since then, assessment of the construct has taken root in various countries, originating research aimed at improving the scale and even leading to the development of other instruments based on it. In Brazil, Ambiel and Noronha (2012a) developed a scale for assessing the construct. Known as the Escala de Autoeficácia para Escolha Profissional (Career Choice Self-Efficacy Scale), its purpose is to assess people's confidence in their ability to make career choices. The scale consists of four factors (self-assessment, occupational data collection, practical vocational data searching, and future planning), plus an overall score (Ambiel \& Noronha, 2012b). Recent studies have confirmed the consistency of the scale's structure and the adequacy of its items (Ambiel, Noronha, \& Carvalho, 2015).

Earlier, dealing with another are a within the context of career counseling, Nunes and Noronha $(2008,2011)$ introduced an instrument known as the Scale of Self-Efficacy for Occupational Activities (EAAOc; initials in Portuguese), aiming at assessing perception of ability to carry out certain professional activities, according to Holland's typology of interests. In the instrument, the authors also proposed a session for assessing the sources of self-efficacy for such activities and identified two factors: one that is associated with genuine experiences (which combines personal experiences, verbal persuasion and physiological indicators); and the other, with vicarious learning.

In a review we conducted of the literature on the subject, this instrument was the only one we were able to locate in Brazil that relates to assessing self-efficacy sources within the career context; other than this instrument, in Brazil there is a scale for assessing this construct in relation to teachers (Iaochite \& Azzi, 2012). At the international level, one finds studies focusing on this construct in other areas, such as mathematics (Lent, Lopez, Brown, \& Gore, 1996; Usher, 2009; Usher \& Pajares, 2009) and sciences (Britner \& Pajares, 2006); students' writing skills (Pajares, Johnson, \& Usher, 2007); and the academic context (Ahn, et al., 2016; Hampton \& Mason, 2003; Joët, Bressoux, \& Usher, 2011; Usher \& Pajares, 2006, 2008). The majority of such studies were conducted in the United States.

Assessing sources of career choice self-efficacy becomes relevant with respect to optimizing self-efficacy belief intervention and development because such beliefs offer individuals more security and less anxiety in the career decisionmaking process (Lent et al., 1994). Furthermore, teenagers, who are the key players in career decision making, are susceptible to external and internal influences that directly affect the devel- 
opment of their self-efficacy beliefs (Lopes \& Teixeira, 2012; Matias et al., 2009).

Because of the importance of self-efficacy sources within this context, the present study's aim is to describe the development process of the Career Choice Self-Efficacy Source Scale (EFAEP; initials in Portuguese), seek validity evidence based on its internal structure and on correlations with other variables, and estimate its indices of accuracy. Accordingly, in light of the importance of developing psychometrically effective instruments for the practice of psychology in relation to career counseling, the instrument presented in the present article receives special emphasis, offering the opportunity to interpret data deriving from the Social Cognitive Theory and apply it within the context of adolescents' career development.

\section{Development of the Career Choice Self-Efficacy Source Scale (EFAEP)}

With respect to the Career Choice SelfEfficacy Source Scale's development, two instruments were employed as references: The self-efficacy source assessment section of Nunes and Noronha's (2011) Scale of Self-Efficacy for Occupational Activities (EAAOc; initials in Portuguese) was our principal model, while Ambiel and Noronha's (2012b) Career Choice Self-Efficacy Scale (EAE-EP; initials in Portuguese) was employed since it is a measure of self-efficacy in this field and because it provides convergent validity.

Accordingly, the items of the EAAOc's source scale were rewritten taking into consideration the factors proposed in the EAE-EP: self-efficacy (SE) for self-assessment; SE for occupational data collection; SE for practical vocational data searching; and SE for future planning. Along these lines, we sought to produce items by adapting the EAAOc's already existing items or by formulating new items that were related to a certain source of a specific factor of self-efficacy for making career choices. For example, the item "I feel good when I engage in this activity," which originally assessed the EAAOc's Personal Experience source, was adapted to assess the same source in relation to self-efficacy for mak- ing career choices, ending up being expressed in the following manner: "I feel good when I contemplate choosing the profession I identify with". In this fashion, we devised 145 items.

Having concluded the above phase, we emailed the items to one of the EAAOc's authors, who assessed the items and recommended several modifications in relation to the way they were written. As anticipated, we discarded most of the items because of the similarity of their content. As a result, we ended up retaining 44 items, which were those that had been given the best assessments by the EAAOc's author and that adhered to the proposed corrections and grammatical modifications. Subsequent to conducting a general review, we perceived that numerous statements still exhibited similar content, indicating the need for further modifications. As a result, 9 more items were excluded, leaving a remainder of 35 items that were actually employed in the preliminary version of the new scale. Upon concluding this process, we noticed that at this point in the instrument's development the self-efficacy sources lacked proportionate representation. Accordingly, we formulated 14 new statements, which together with those that had been adapted amounted to 49 items.

Continuing this process, we sent the 49 statements to one of the EAAOc's authors for further assessment. During this phase, we punctually received comments and suggestions recommending alterations in the items' wording and the exclusion of one item due to similar content. Upon completion of the instrument's developmental phase, the EFAEP was left with 48 items in all: 8 for the Verbal Persuasion source, 10 for the Personal Experiences source, 12 for the Physiological Indicators source and 18 for the Vicarious Learning source. With respect to the instructions concerning the answer options, we opted for maintaining the original EAAOc format, featuring a five-point Likert scale, whereby values closer to 1 signify "agree less" with the situations described in the statements; and closer to 5 , "agree more."

During the second phase of the EFAEP's development, we initiated a preliminary datacollection survey of five high school students 
who had submitted informed consent forms signed by their parents/guardians. The survey was administered individually, at various locations. The participants were requested to answer the questionnaire and fill out a form aimed at assessing their comprehension of the instrument's instructions and items.

Most of the students had no problem understanding the items, and only one stressed the need to improve the instructions concerning the answer options. Upon the pilot survey's conclusion and in light of this student's suggestion, the scale underwent a second revision, whereby the instructions regarding the answer options were modified to ease comprehension, ending up with the following wording: Values close to 1 mean that you "slightly agree" with the situations described in the statements and close to 5 that you "considerably agree." In this manner, the instrument's developmental phase came to an end and the data collection phase began, seeking other evidence of validity and accuracy.

\section{Method}

\section{Participants}

The sample was made up of 388 students (61.6\% female, $38.4 \%$ male) from 14 to 19 years of age $(M=15.9, S D=1.0)$. The students came from two public schools [a technical school $(n=$ $92)$ and an ordinary high school $(n=66)]$, a private school $(n=56)$, an SESI school $(n=67)$ and an association of young apprentices $(n=107)$. All of these educational institutions are located in three cities in the interior of the state of São Paulo.

\section{Instruments}

The Career Choice Self-Efficacy Source Scale (EFAEP) is made up of 48 items for evaluating high school students' self-efficacy information sources, which are employed to develop or strengthen beliefs in self-efficacy to engage in activities involving career choices. Examples of the scale's items as well as the analyses that were made using the instrument are presented in the "Results" section below. The answer options are in the form of a five-point Likert scale, whereby values close to 1 signify that the respondent "slightly agrees" with the situations described in the statements, and values close to 5 signify "considerably agrees."

Developed by Ambiel and Noronha (2012b), the Career Choice Self-Efficacy Scale (EAEEP) was also employed. Its purpose is to assess people's beliefs as to their ability to engage in career decision-making tasks. It is composed of 47 items that are distributed among four selfefficacy factors (self-assessment, occupational data collection, practical vocational information searching, and future planning), plus the overall score. The answer options are in the form of a 4-point Likert scale that assesses the intensity of the respondents' self-efficacy beliefs, ranging between 1 ("slight") and 4 ("considerable"). The instrument's factor structure was obtained via factor analysis. It exhibited relatively high accuracy, with a Cronbach's alpha coefficient ranging from 0.79 to 0.88 for the factors and 0.94 for the overall score. In the present study, the alphas varied between 0.75 and 0.86 for the factors and 0.92 for the overall score.

\section{Data Collection Procedures}

Data collection was conducted on days and in time slots times that were previously scheduled with the schools. Only students who submitted an informed consent form signed by their parents/guardians (or by the students themselves when over 18) participated in the survey. The EFAEP was administered first, followed by the EAE-EP. The participants took an average of approximately 30 minutes to answer the questionnaires.

\section{Data Analysis Procedures}

The data were tabulated in a spreadsheet and analyzed via IBM SPSS Statistics 20 software. Cases of missing data in the database did not interfere with the analyses, and there was thus no need to exclude participants. Initially, principal component analysis was conducted in order to check the EFAEP's internal structure. To do this, parallel analysis was employed so as to ascertain the number of items to be retained in the components. 
Parallel analysis consists of a simulation of random matrices that are run hundreds or thousands of times, with the same number of variables and subjects as the real database. The random and real eigenvalues are then compared, retaining the real eigenvalues that are greater than 1 and less than the random eigenvalues obtained (Damásio, 2012). In the present study, parallel analysis was performed using the Parallel Engines web site (Patil, Singh, Mishra, \& Donovan, 2007), employing 1000 matrices and a $95 \%$ confidence interval. The factors' internal consistency was also checked via Cronbach's alpha. Aiming at assessing the correlations between the instruments, we employed the Pearson correlation coefficient $(r)$, with correction for attenuation due to the instruments' measurement errors by way of the Spearman-Brown adjustment, as recommended by Cohen and Cohen (1983).

\section{Ethical Procedures}

At the outset, we contacted the educational institutions to request the students' participation in the present study. Subsequent to receiving authorization from the schools, the project was submitted to the Research Ethics Committee for approval. Furthermore, throughout the course of data collection, we complied with all of the ethical safeguards required for research involving human beings.

\section{Results}

Principal component analysis of the EFAEP was conducted using direct oblimin rotation, which produced a KMO of 0.86 and a significant Bartlett's Test of Sphericity result $(p<.001)$. Factorization of the set of items with the possibility of up to 13 components with eigenvalues greater than 1 was also indicated (Kaiser criterion). By way of parallel analysis, we identified the possibility of extracting up to seven factors. Nonetheless, based on the literature concerning selfefficacy sources, we opted for forcing a structure with up to four factors, obtaining a total of $37 \%$ of the explained variance. The criterion for retaining items was to retain those with a factor loading of 0.30 or higher. As a result, 7 of the 48 items were excluded.

The four-factor structure ended up with the following configuration: Factor 1 consisted of 12 items, most of which were statements related to the Verbal Persuasion source, although three of the items encompassed content that was different from the content proposed for that source. Factor 2 ended up with 9 items, part of which involved content related to the Vicarious Experiences source, while the other part encompassed content associated with the Physiological Indicators source. Since it contained various problematic items (i.e. ambiguously worded items), it was not possible to identify the self-efficacy information source to which such items actually belonged. Factor 3 ended up being made up of 10 items related to the Vicarious Learning selfefficacy source. Lastly, Factor 4 finished up with 10 items related to the Personal Experiences source. In this structure of up to four factors, we identified two components containing problematical groups of items, due to the fact that they mix items of more than one factor. Factor 1 contained three items unrelated to the source that was being represented, and Factor 2 mixed items related to two self-efficacy sources.

Subsequent to reviewing the literature concerning self-efficacy belief sources and analyzing the scale's items, we observed that the items we formulated to address the Physiological Indicators source were written principally taking into consideration emotional issues related to career choices, without also considering the physiological issues. It is worth stressing that the Physiological Indicators self-efficacy source corresponds to the assessment individuals make concerning their self-confidence to perform a certain activity, based on the information furnished by their physiological and emotional state (Nunes, 2008).The instrument was thus unable to gather together items that satisfactorily represent the Physiological Indicators source to the extent of representing one specific factor.

Due to the problems detected in the fourfactor structure, we performed another principal component analysis, prior to which we excluded the 12 items that exhibited problems in relation 
to this structure. This second analysis was conducted using direct oblimin rotation, yielding a KMO of 0.86 and a significant Bartlett's Test of Sphericity result $(p<.001)$. By way of parallel analysis, we identified the possibility of extracting up to three factors, thus forcing the structure, obtaining $40 \%$ of the explained variance. We employed the same criterion for item retention (factor loading greater than 0.30). We also tested a two-factor structure. Nonetheless, the threefactor structure exhibited a better fit, from both a psychometric and theoretical standpoint. With the three-factor structure, we excluded 11 more items because they did not obtain the stipulated factor loading, resulting in a final total of $23 \mathrm{ex}-$ cluded items and 25 retained items, as shown in Table 1.

Table 1

Grouping of EFAEP Items in the Factors - Three-Factor Structure

Factors

Items

$1 \quad 2 \quad 3$

47

I feel enthusiastic when I accompany the daily routine of a professional from the field I like.

I notice that students taking courses that interest me have characteristics similar to mine.

I feel happy when I visit a company that operates in the field I want to work in.

Attending lectures about the field I want to work in makes me happy.

I perceive that I have skills similar to those of professionals in the field I like.

I feel accomplished when performing an activity similar to the profession I want to choose.

I usually observe the field's professionals in order to learn about what they do. motivates me.

I've noticed that professionals in the field I'm interested in have opinions I identify with.

My family usually says it's proud of the way I'm concerned about my future.

I feel at ease when I think about the financial return the profession I'm interested in can offer me.

I'm familiar with the financial return that the profession I like can offer me. 
31

Number of items

Cronbach's alpha
Using a computer has made it easier for me to find information about undergraduate courses.

\section{the course I like.}

I find it easy to deal with new information about courses and careers.
Factor 1was designated to receive items representing the Vicarious Learning self-efficacy information source, with a total of 9 items and a Cronbach's alpha of 0.80 . In this factor, however, one observes four items that were developed to specifically represent the Vicarious Learning source and five items designed to represent the Physiological Indicators source. Nonetheless, despite the fact that there are more items pertaining to the latter source, one notes that they contain ambiguous content and that their wording is more representative of the Vicarious Learning source. Meanwhile, Factor 2 retained items related to the Verbal Persuasion source, and they involve statements that were worded to specifically represent that source. This factor ended up with 7 items and exhibited a consistency of 0.81 .
Lastly, Factor 3 consisted of 9 items related to the Personal Experiences source, yielding an alpha of 0.73 . Most of this factor's items were designed to represent the Personal Experiences source, although it also contains two items written for the Physiological Indicators source and one item developed for the Vicarious Learning source. With this structure, the Career Choice Self-Efficacy Source Scale was able to satisfactorily represent three sources of self-efficacy for making career choices.

Aiming at obtaining validity evidence based on correlations with other variables, subsequent to performing factor analysis of the EFAEP we checked for correlations between the EFAEP's factors and the EAE-EP's factors. In this case, the correlations were attenuated, controlling the effect of both instruments' measurement errors. The resulting coefficients are displayed in Table 2 .

Table 2

Attenuated Correlations between the Factors of the EFAEP and EAE-EP

\begin{tabular}{cccccc}
\hline Self-efficacy sources & $\begin{array}{c}\text { Self-assessment } \\
\text { self-efficacy }\end{array}$ & $\begin{array}{c}\text { Occupational } \\
\text { data collection } \\
\text { self-efficacy }\end{array}$ & $\begin{array}{c}\text { Practical vocational } \\
\text { data searching } \\
\text { self-efficacy }\end{array}$ & $\begin{array}{c}\text { Future planning } \\
\text { self-efficacy }\end{array}$ \\
\hline Vicarious Learning & $r$ & $0.59^{*}$ & $0.46^{*}$ & $0.63^{*}$ & $0.32^{*}$ \\
Verbal Persuasion & $r$ & $0.55^{*}$ & $0.55^{*}$ & $0.44^{*}$ & $0.31^{*}$ \\
Personal Experience & $r$ & $0.47^{*}$ & $0.56^{*}$ & $0.34^{*}$ & $0.66^{*}$ \\
\hline
\end{tabular}

$* p \leq .001$.

One observes that all of the correlations are both positive and significant, with magnitudes ranging from low to moderate, according to Dancey and Reidy's (2006) specifications. Standing out among these correlations are those with the highest magnitudes, which can be observed between the Vicarious Learning source and the factors associated with practical vocational data searching self-efficacy $(r=$ $0.63)$ and self-evaluation self-efficacy $(r=0.59)$, 
and between the Personal Experiences source and the future planning self-efficacy factor ( $r=$ $0.66)$.

\section{Discussion}

Making a career choice is a complex moment in an adolescent's life, involving various variables that influence his/her decision. At this point in life, psychology, through the career counseling process, offers young people several tools that can help them clear up their doubts and organize the information they receive (Noronha \& Ambiel, 2006). It is within this context that assessing self-efficacy and its sources becomes relevant since it offers adolescents an analysis of the activities they believe they do well and promotes expectations of positive results (Lent et al., 1994). In light of the foregoing, the present study aimed to describe the development process of the Career Choice Self-Efficacy Source Scale (EFAEP), an instrument that makes it possible to assess the self-efficacy information sources that are employed in the formation and strengthening or weakening of adolescents' self-efficacy beliefs.

While developing the EFAEP, we sought to devise items that would make it possible to assess all four self-efficacy sources, based on Bandura's (1997) research. One of the instruments that were employed as references for the EFAEP's development is the current version of the EAAOc, which consists of two factors for assessing self-efficacy information sources. One of the factors focuses on vicarious experiences (vicarious learning) alone; and the other factor, on the genuine experiences that people undergo, relating to the personal experiences, verbal persuasion and physiological indicators sources (Nunes \& Noronha, 2011). The other instrument we employed as a reference for measuring career choice self-efficacy provided a basis for the EFAEP's items in this area of career development. The items' development process focused on the specific moment of choosing an undergraduate program or profession.

With respect to the principal component analyses of the EFAEP, we observed that it was unfeasible to group the items into four factors, which would be the standard procedure according to the theory concerning self-efficacy sources (Bandura, 1997). The chief reason for such incompatibility with the theory relates to the way the items were worded to focus on the Physiological Indicators source. According to Pajares (2002), based on their emotional and physiological states, individuals can assess their ability to engage in a certain activity. Subsequent to conducting a theoretical review, we perceived that this item's source did not take into consideration the individual's physiological state at the time of making a career choice, focusing chiefly on the individual's emotional state. It is worth emphasizing that this self-efficacy source involves both emotional and physiological states. The most frequent reactions, such as stress, tachycardia and sweating, can manifest themselves in various situations, and the degree to which they are manifested is considered an indication of ability.

Due to the fact that the items did not address such issues, it was not possible for us to achieve our goal of assessing the self-efficacy sources in terms of all four factors. We also did not come across the four-factor structure in other studies, such as the study conducted by Nunes and Noronha (2008, 2011), which first presented a three-factor structure for the EAAOc and, subsequently, a two-factor structure. Similarly, studies conducted by Anderson and Betz (2001) and by Gainor and Lent (1998) also evidenced different structures.

Furthermore, there was a tendency towards grouping together items related to both the Vicarious Learning source and the Physiological Indicators source, which can be observed in both the initial, four-factor structure and the subsequent, three-factor structure we adopted for the instrument. This can be attributed to the manner in which the items were worded: To a certain extent, their content was ambiguous, and they were thus capable of being interpreted as items that relate to both of these self-efficacy sources. In the three-factor structure that we adopted, it became even more evident that the statements formulated for the Physiological Indicators source 
were ambiguous and that they related more to the Vicarious Learning source than to the Physiological Indicators source, an observation that was essential to determining that EFAEP Factor 1 is aimed at assessing the Vicarious Learning source.

One observes that the EFAEP's third factor, which represents the Personal Experiences source of self-efficacy information, contains items related to the individual's prior futureplanning endeavors, such as choosing an undergraduate course or a profession and its financial benefits. Such content concerning career choice self-efficacy corroborates the data that is assessed by the EAE-EP, which has a specific factor for assessing future planning focused on financial issues (Ambiel \& Noronha, 2012b).

In fact, the results also demonstrate that several modifications are required in order to make the best use of the scale, principally with respect to the revision of existing items and formulation of new items and the performance of an analysis by judges. Even so, excluding the items that did not function properly within this structure, one observes that the factors exhibit both a proportionate distribution of items and theoretical coherence, providing equilibrium for the assessment of the sources and yielding validity evidence based on a favorable internal structure. From a psychometric standpoint, the scale displays good internal reliability adjustments, with only one of the three components exhibiting an adjustment lower than 0.80 (Prieto \& Muñiz, 2000).

Based on the correlations identified between the EFAEP and EAE-EP's factors, we also examined the relationship between the constructs, which is consistent with the theory concerning self-efficacy sources and beliefs. Furthermore, the highest values corroborate the more specific relationship between the factors, as one observes between the Vicarious Learning source and the practical vocational data searching self-efficacy factor, both of which involve observing other people and gathering, from other individuals, information that aids career decision making. Similarly, one observes a correlation between the Personal Experiences source and the future planning self-efficacy factor, whose items, as afore mentioned, focus on issues related to a future career, focusing especially on financial considerations. With such correlations as a starting point, we also obtained validity evidence based on correlations with external variables.

\section{Final Considerations}

In the field of psychological evaluation, and especially in relation to career counseling, there is an increasing need for the development of assessment instruments with acceptable psychometric properties. The present study strove to satisfy this need, so that in the long term the EFAEP will become available for psychologists' professional use. Furthermore, this study also contributes to the dissemination of information concerning self-efficacy and its sources as applied to career counseling within the Brazilian context, an area that is still insufficiently studied by researchers.

The presentation of this instrument is also relevant to there search field because it furnishes a tool for testing the SCCT's theoretical hypotheses, such as testing self-efficacy information sources' predictive capacity in relation to career self-efficacy beliefs. With respect to the scale's importance to psychological assessment, the awareness and study of the information sources that young people draw on to form their self-efficacy beliefs is relevant since it is a way of helping such people at the critical moment of choosing an undergraduate course or a career.

Nonetheless, the EFAEP has its shortcomings, such as the fact that it does not possess a factor structure that clearly represents the four self-efficacy sources. This draw back could be due to the fact that the Physiological Indicators source does not prioritize physiological factors that can influence career choices. However, it could also be attributed to the ambiguousness of the items' wording. There is a tendency for the statements (which were initially written to represent the Physiological Indicators source) to be interpreted as items pertaining to the $\mathrm{Vi}$ carious Learning source since they are even 
more representative of this source. Even so, the factor structure adopted for the EFAEP still exhibits adjusted indices demonstrating accuracy and theoretical coherence, indicating that it enjoys evidence of validity based on the internal structure.

A further short coming of the study is that it surveyed students from only one region of Brazil, as well as the fact that it did not employ other methods for assessing the EFAEP's items, such as an analysis conducted by judges. In future studies involving this scale, we recommend revising its items and formulating new items, testing its psychometric properties, and administering it to students from other Brazilian states.

\section{References}

Ahn, H. S., Usher, E. L., Butz, A., \& Bong, M. (2016). Cultural differences in the understanding of modeling and feedback as sources of selfefficacy information. British Journal of Educational Psychology, 86(1), 112-136. doi:10.1111/ bjep.12093

Ambiel, R. A. M., Noronha, A. P. P., \& Carvalho, L. F. (2015). Analysis of the Professional Choice Self-Efficacy Scaleusing Rasch-Andrich rating scale model. International Journal for Educational and Vocational Guidance, 15(3), 205219. doi:10.1007/s10775-015-9293-7

Ambiel, R. A. M., \& Noronha, A. P. P. (2012a). Autoeficácia para escolha profissional: Teoria, pesquisas e avaliação. Psicologia em Pesquisa, 6(02), 171-178. doi:10.5327/Z198212472012000200010

Ambiel, R. A. M., \& Noronha, A. P. P. (2012b). Escala de autoeficácia para escolha profissional. Manual Técnico. São Paulo, SP: Casa do Psicólogo.

Anderson, S. L., \& Betz, N. E. (2001). Sources of social self-efficacy expectations: Their measurement and relation to career development. Journal of Vocational Behavior, 58(1), 198-117. doi:10.1006/jvbe.2000.1753

Azzi, R. G., Vieira, D. A., Iaochite, R. T., Ferreira, L. C. M., \& Guerreiro-Casanova, D. C. (2014). Crenças de eficácia pessoal e coletiva. In R. G. Azzi \& D. A. Vieira (Eds.), Crenças de eficácia em contexto educativo (pp. 15-40). São Paulo, SP: Casa do Psicólogo.

Bandura, A. (1977). Self-efficacy: Toward a unifying theory of behavioral change. Psychological Review, 84(2), 191-215. doi:10.1037/0033295X.84.2.191

Bandura, A. (1997). Self-efficacy: The exercise of control. New York: W. H. Freeman and Company.

Bandura, A. (2008). A teoria social cognitiva na perspectiva da agência. In A. Bandura, R. G. Azzi, \& S. A. J. Polydoro (Eds.), Teoria social cognitiva, conceitos básicos (pp. 69-96). Porto Alegre, RS: Artmed.

Bandura, A. (2009). Cultivate self-efficacy for personal and organizational effectiveness. In E. A. Locke (Ed.), Handbook of principles of organization behavior (2 ${ }^{\text {nd }}$ ed., pp. 179-200). New York: Wiley.

Betz, N. E., \& Luzzo, D. A. (1996). Career assessment and the career decision-making self-efficacy scale. Journal of Career Assessment, 4(4), 413-428. doi:10.1177/106907279600400405

Britner, S. L., \& Pajares, F. (2006). Sources of science self-efficacy beliefs of middle school students. Journal of Research in Science Teaching, 43(5), 485-499. doi:10.1002/tea.20131

Cohen, J., \& Cohen, P. (1983). Applied multiple regression/correlation analysis for the behavioral sciences $\left(2^{\text {nd }}\right.$ ed.). Hillsdale, NJ: Erlbaum.

Damásio, B. F. (2012). Uso da análise fatorial exploratória em psicologia. Avaliação Psicológica, 11(2), 213-228. Retrieved from http://pepsic.bvsalud.org/scielo.php?script=sci_arttext\&p id $=$ S1677-04712012000200007

Dancey, C. P., \& Reidy, J. (2006). Estatística sem matemática para psicologia: Usando SPSS para Windows. Porto Alegre, RS: Artmed.

Gainor, K. A., \& Lent, R. (1998). Social cognitive expectations and racial identity attitudes in predicting the math choice intentions of Black college students. Journal of Counseling Psychology, 45(4), 400-413. doi:10.1037/00220167.45.4.403

Hacket, G., \& Betz, N. E. (1981). A self-efficacy approach to the career development of women. Journal of Vocational Behavior, 18, 326-336. doi:10.1016/0001-8791(81)90019-1 
Hampton, N. Z., \& Mason, E. (2003). Learning disabilities, gender, sources of efficacy, selfefficacy beliefs, and academic achievement in high school students. Journal of School Psychology, 41, 101-112. doi:10.1016/S00224405(03)00028-1

Iaochite, R. T., \& Azzi, R. G. (2012). Escala de fontes de autoeficácia docente: Estudo exploratório com professores de educação física. Psicologia Argumento, 30(71), 659-669. doi:10.7213/psicol.argum. 7472

Joët, G., Bressoux, P., \& Usher, E. L. (2011). Sources of self-efficacy: An investigation of elementary school students in France. Journal of Educational Psychology, 103(3), 649-663. doi:10.1037/ a0024048

Lent, R. W., Brow, S. D., \& Hackett, G. (1994). Towards a unifying social cognitive theory of career and academic interests, choice and performance. Journal of Vocational Behavior, 45(1), 79-122. doi:https://doi.org/10.1006/jvbe.1994.1027

Lent, R. W., Lopez, F. G., Brown, S. D., \& Gore, P. A. (1996). Latent structure of the sources of mathematics self-efficacy. Journal of $\mathrm{Vo}$ cational Behavior, 49, 292-308. doi:10.1006/ jvbe.1996.0045

Lopes, A. R., \& Teixeira, M. O. (2012). Projetos de carreira, autoeficácia e sucesso escolar em ambiente multicultural. Revista Brasileira de Orientação Profissional, 13(1), 7-14. Retrieved from http://pepsic.bvsalud.org/scielo.php?script=sci arttext\&pid=S1679-33902012000100003

Matias, T. S., Rolim, M. K. S. B., Kretzer, F. L., Schmoelz, C. P., Vasconcellos, D. I. C., \& Andrade, A. (2009). Estilo de vida, nível habitual de atividade física e percepção de autoeficácia de adolescentes. Revista da Educação Física, 20(2), 235-243. Retrieved from http://periodicos.uem.br/ojs/index.php/RevEducFis/article/ view/6413

Noronha, A. P. P., \& Ambiel, R. A. M. (2006). Orientação profissional e vocacional: Análise da produção científica. Psico-USF, 11(1), 75-84. Retrieved from http://www.scielo.br/pdf/pusf/ v11n1/v11n1a09

Nunes, M. F. O. (2008). Funcionamento e desenvolvimento das crenças de auto-eficácia: Uma revisão. Revista Brasileira de Orientação Profissional, 9(1), 29-42. Retrieved from http://pep- sic.bvsalud.org/scielo.php?script=sci arttext\&p $\mathrm{id}=$ S1679-33902008000100004

Nunes, M. F. O., \& Noronha, A. P. P. (2008). Escala de auto-eficácia para atividades ocupacionais: Construção e estudos exploratórios. Paidéia (Ribeirão Preto), 18(39), 11-124. doi:10.1590/ S0103-863X2008000100011

Nunes, M. F. O., \& Noronha, A. P. P. (2011). Escala de Autoeficácia para Atividades Ocupacionais: Estudo da estrutura interna e precisão. Avaliação Psicológica, 10(1), 25-40. Retrieved from http:// pepsic.bvsalud.org/scielo.php?script=sci_arttext \&pid $=$ S1677-04712011000100004

Pajares, F. (2002). Overview of social cognitive theory and of self-efficacy. Retrieved from http:// www.emory.edu/EDUCATION/mfp/eff.html

Pajares, F., Johnson, M. J., \& Usher, E. L. (2007). Sources of writing self-efficacy beliefs of elementary, middle and high school students. Research in the Teaching of English, 42(1), 104-120. Retrieved from http://sites.education. uky.edu/motivation/files/2013/08/PajaresJohnsonUsherRTE2007.pdf

Pajares, F., \& Olaz, F. (2008). Teoria social cognitiva e auto-eficácia: Uma visão geral. In A. Bandura, R. G. Azzi, \& S. A. J. Polydoro (Eds.), Teoria social cognitiva, conceitos básicos (pp. 97-114). Porto Alegre, RS: Artmed.

Patil, V. H., Singh, S. N., Mishra, S., \& Donavan, D. T. (2007). Parallel Analysis engine to aid determining number of factors toretain [Computer software]. Retrieved from http://ires. $\mathrm{ku} . \mathrm{edu} / \sim \mathrm{smishra} /$ parallelengine.htm

Prieto, G., \& Muñiz, J. (2000). Un modelo para evaluar la calida de los tests utilizados em España. Papeles del Psicólogo, 77, 1-10. Retrieved from http://www.papelesdelpsicologo.es/vernumero. asp?id $=1102$

Taylor, K. M., \& Betz, N. E. (1983). Applications of self-eficacy theory to the understanding and treatment of career indecision. Journal of Vocational Behavior, 22, 63-81. doi:10.1016/00018791(83)90006-4

Usher, E. L. (2009). Sources of middle school students' self-efficacy in mathematics: A qualitative investigation. American Educational Research Journal, 46(1), 275-314. doi:10.3102/0002831208324517 
Usher, E. L., \& Pajares, F. (2006). Sources of science self-efficacy beliefs of middle school students. Journal of Research in Science Teaching, 43(5), 485-499. doi:10.1002/tea.20131

Usher, E. L., \& Pajares, F. (2008). Sources of self-efficacy in school: Critical review of the literature and future directions. Review of Educational Research, 78(4), 751-796. doi:10.3102/0034654308321456
Usher, E. L., \& Pajares, F. (2009). Sources of self-efficacy in mathematics: A validation study. Contemporary Educational Psychology, 34, 89-101. doi:10.1016/j.cedpsych.2008.09.002

Received: 25/06/2016

$1^{\text {st }}$ revision: $17 / 11 / 2016$

$2^{\text {nd }}$ revision: $19 / 01 / 2017$

Accepted: 19/01/2017

(C) The Author(s), 2018. Open Access. This article is distributed under the terms of the Creative Commons Attribution 4.0 International License (http://creativecommons.org/licenses/by/4.0/), which permits unrestricted use, distribution, and reproduction in any medium, provided you give appropriate credit to the original author(s) and the source, provide a link to the Creative Commons license, and indicate if changes were made. 